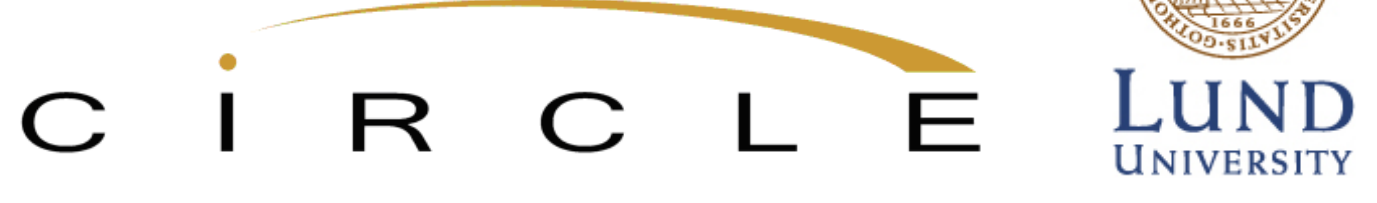

\title{
Linking content and technology: On the geography of innovation networks in the Bergen media cluster
}

\author{
Roman Martin (roman.martin@handels.gu.se) \\ Gothenburg University and CIRCLE, Lund University, Sweden \\ Jan Ole Rypestøl (jan.o.rypestol@uia.no)
} Department of Working Life and Innovation, University of Agder, Norway

\section{Papers in Innovation Studies \\ Paper no. 2019/01}

This is an Accepted Manuscript of an article published by Taylor \& Francis Group in Industry and Innovation on 23/06/2017 available online: $\mathrm{http} / / / \mathrm{dx}$. doi.org/10.1080/13662716.2017.1343132

Centre for Innovation, Research and Competence in the Learning Economy (CIRCLE)

Lund University

P.O. Box 117, Sölvegatan 16, S-221 00 Lund, SWEDEN

http://www.circle.lu.se/publications 
WP 2019/01

\title{
Linking content and technology: On the geography of innovation networks in the Bergen media cluster
}

Roman Martin, Jan Ole Rypestøl

\begin{abstract}
This paper deals with the geography of innovation networks and analyses combinatorial knowledge dynamics from a single cluster perspective. Addressing firms in the media cluster in Bergen, Norway, we examine how and from where companies acquire and combine different types of knowledge for their innovation activities. The empirical analysis, which is based on structured interviews with 22 media companies, identifies two main types of cluster firms: media content providers that rely heavily on symbolic knowledge and media technology providers that draw mostly on synthetic knowledge. Even though they draw on different knowledge bases, the two types of firms are strongly interlinked in their innovation activities and source knowledge from each other. Furthermore, we find that synthetic firms constitute a gateway to the regional R\&D system and that the region acts as key arena for the combination of dissimilar knowledge bases.
\end{abstract}

Keywords: innovation networks; knowledge bases; creative industries; new media, Norway

JEL Codes: L82 ; 014; O30; O31

Disclaimer: CIRCLE does not take any responsibility for opinions and views expressed by the authors in this paper. 
Title:

\title{
Linking content and technology: On the geography of innovation networks in the Bergen media cluster
}

\author{
This is an Accepted Manuscript of an article published by Taylor \& Francis Group in \\ Industry and Innovation on 23/06/2017, available online: \\ http://dx.doi.org/10.1080/13662716.2017.1343132
}

\begin{abstract}
Authors:
Roman Martin (roman.martin@handels.gu.se)

Department of Business Administration, University of Gothenburg, Sweden, and CIRCLE, Lund University, Sweden

Jan Ole Rypestøl (jan.o.rypestol@uia.no)

Department of Working Life and Innovation, University of Agder, Norway
\end{abstract}


Abstract: This paper deals with the geography of innovation networks and analyses combinatorial knowledge dynamics from a single cluster perspective. Addressing firms in the media cluster in Bergen, Norway, we examine how and from where companies acquire and combine different types of knowledge for their innovation activities. The empirical analysis, which is based on structured interviews with 22 media companies, identifies two main types of cluster firms: media content providers that rely heavily on symbolic knowledge and media technology providers that draw mostly on synthetic knowledge. Even though they draw on different knowledge bases, the two types of firms are strongly interlinked in their innovation activities and source knowledge from each other. Furthermore, we find that synthetic firms constitute a gateway to the regional $\mathrm{R} \& \mathrm{D}$ system and that the region acts as key arena for the combination of dissimilar knowledge bases.

Keywords: innovation networks, knowledge bases, creative industries, new media, Norway

JEL Codes: L82 ; O14; O30; O31

Acknowledgements: We are grateful for the comments by Arne Isaksen on an earlier version of this paper. We also want to thank the anonymous reviewers for their constructive critique. All the usual caveats apply.

Funding: This work was generously supported by the Research Council of Norway (project number 12820398), the Marianne and Marcus Wallenberg Foundation (project number MMW 2012.0194), and the Jan Wallander and Tom Hedelius Foundation (postdoctoral research grant W2013-0215:1). 


\section{Introduction}

In economic geography and related disciplines, there is an increasing interest in the question how and from where firms acquire new knowledge for innovation. Despite the ongoing globalisation, the regional level is typically seen as key locus for interactive learning and knowledge exchange (Asheim and Gertler 2005, Moulaert and Sekia 2003). Consequently, policy makers seek to strengthen economic competitiveness through regionally oriented policy approaches, based on concepts such as clusters, in particular by fostering networking between innovative actors, including firms, universities, and public support organisations. ${ }^{1}$ Studies on the geography of innovation networks, however, have shown that firms acquire knowledge not only locally, but from multiple geographical scales, which requires policy approaches that cross regional boundaries. Furthermore, the importance of local knowledge networks has shown to differ between industries with different knowledge base (Martin and Moodysson 2013, Plum and Hassink 2014). In addition to industry specific differences, it has also become apparent that firms engage not only into collaborative networks, but use multiple knowledge sourcing channels. While research on the geography of knowledge networks typically relies on measures of inter-organisational collaboration such as co-publications or joint R\&D projects (e.g. Fitjar, Huber, and Rodríguez-Pose 2016, McKelvey and Rake 2016), research on non-collaborative knowledge exchange is relatively scarce. The question whether different network channels entail different geographies has not been scrutinized systematically, which is one research gap this paper attempts to fill.

Furthermore, while earlier literature argued that clusters are naturally dominated by either analytical, synthetic or symbolic knowledge bases (e.g. Tödtling, Asheim, and Boschma 2013, Asheim and Gertler 2005), more recent contributions stress that firms usually combine two or

\footnotetext{
${ }^{1}$ See, for instance, the Research Council of Norway's Programme for Regional R\&D and Innovation (VRI) (RCN 2013).
} 
more knowledge bases in the innovation process (Grillitsch, Martin, and Srholec 2016, Manniche, Moodysson, and Testa 2016), and that clusters can change their dominant knowledge base over time (Ingstrup, Jensen, and Christensen 2017, Martin and Trippl 2015). The combination of knowledge bases have been studied at the firm level, but may also take place at the level of a cluster. In line with that, this paper contributes with an analysis of knowledge base combinations from the perspective of a single cluster.

The empirical analysis is based on novel data collected through interviews with firm representatives in the media cluster in Bergen, Norway. The media sector is considered as artistic and cultural industry, in which symbolic knowledge, aesthetic values and design play a central role (Cooke 2010, Grabher 2002, Mossig 2004). Due to the ongoing digital convergence (i.e. the convergence of ICT and media content), however, innovation in this industry is not only about the generation of media content based on symbolic knowledge, but increasingly also about the application and development of media technologies, for which synthetic knowledge is critical. How and from where firms (in the media industry in Bergen) source and combine different types of knowledge is a key issue addressed in this paper.

The paper is structured as follows. Section 2 provides a theoretical framework by combining insights from the literature on knowledge bases, knowledge sourcing channels and proximity dimensions. Section 3 introduces the empirical case and presents the data and method. Section 4 comprises an analysis of knowledge flows and networks between firms and other organisations in the Bergen media cluster. Section 5 concludes the findings and draws implications for future research. 


\section{Theoretical framework: The geography of knowledge sourcing}

One of the key issues in economic geography is the question why innovation concentrates in certain locations. The core argument for explaining spatial clustering of innovation activities is that the transfer of knowledge, which is the most important input for innovation, is facilitated by geographical proximity: it is easier to exchange knowledge between economic actors that are co-located, whereas additional efforts are needed to overcome spatial distance.

In this context, knowledge should not be seen a homogenous, but can come in different forms with different sensitivities to proximity and distance. A common way to classify knowledge is into codified and tacit, and while the first can be written down and easily transferred over time and distance, the latter is embodied into humans, can be best transferred though face-to-face interactions and is therefore spatiality sticky (Polanyi 1967, Gertler 2003). Although the 'tacit versus codified' dichotomy has been widely used, it tends to reinforce one of the main conceptual binaries in human geography, that is, 'local versus global' (Cox 2005, Cloke and Johnston 2005). In line with the observation that innovation often involves both tacit and codified knowledge (Nonaka, Toyama, and Konno 2000, Johnson, Lorenz, and Lundvall 2002), innovation can equally well depend on a combination of local and global knowledge sources. Some authors stress that neither the exchange of tacit nor the exchange of codified knowledge is restricted to a particular geographical scale, as firms can use different communication channels to acquire new knowledge both locally and globally (Asheim and Isaksen 2002, Belussi and Pilotti 2002, Moodysson 2008). Others stress that geographical proximity is neither a necessary nor a sufficient condition for knowledge exchange, as other types of proximities need to be present for successful knowledge transfer (Torre and Gilly 2000, Boschma 2005).

Based on these considerations and in order to understand how and from where firms acquire and combine different types of knowledge, it is important to elaborate more on 1) the type of 
knowledge sourced and combined for innovation, 2) the type of knowledge sourcing channels used by firms, 3) and the type of proximity between innovative actors. These three analytical dimensions are discussed in the following.

\subsection{Differentiated knowledge bases and their combinations}

One way to further study geographical patterns of innovation is by considering the type of knowledge that is sourced and exchanged in the innovation process. While tacit versus codified is one possible knowledge typology, the literature on knowledge bases aims at moving beyond this dichotomy (e.g. Laestadius 1998, Moodysson 2007, Gertler 2008, Asheim, Boschma, and Cooke 2011). Asheim and Gertler (2005) argue that "the innovation process of firms is also strongly shaped by their specific knowledge base, which tends to vary systematically by industrial sector" (Asheim and Gertler 2005, 295, emphasis in the original). Three types of knowledge bases can be distinguished; namely, analytical, synthetic and symbolic, which differ in various respects such as the rationale for knowledge creation, the development and use of knowledge, the actors involved and the role of spatial proximity in the innovation process (Asheim, Boschma, and Cooke 2011). Innovation in analytical industries aims at the development of new knowledge about natural systems by applying scientific laws. Innovation involves strongly codified and universally valid knowledge content, which is little restricted to a specific socio-cultural context. Synthetic industries innovate by applying existing knowledge in new ways. Innovation takes the form of concrete problem solving and interactive learning with customers and suppliers. Innovation in symbolic industries aims at the creation of meaning, desire and aesthetic assets. Interpretation and cultural knowledge is essential and to a high degree determined by the socio-cultural context.

The knowledge base typology has been applied to study industry specific differences in innovation networks. Studies show clear differences between innovation networks in analytical, 
synthetic and symbolic industries (Plum and Hassink 2011, Martin and Moodysson 2013, Herstad, Aslesen, and Ebersberger 2014, Martin 2013). Knowledge exchange in analytical industries tends to be globally organized and include universities and other R\&D organizations as important knowledge hubs. Knowledge exchange often takes place in epistemic communities and with highly specialised knowledge providers in different parts of the world. In synthetic industries, cooperation and knowledge exchange often occurs between firms in the value chain and builds on trust and reciprocity earned through repeated interactions. Relatively little collaboration takes place over far geographical distance, while national or regional networks prevail. Innovation in symbolic industries is even more governed by the local context, and companies cooperate with a number of altering partners in close geographical proximity. Companies change their cooperation partners frequently. They are tied together for the short period of a project before they switch to other projects and other collaboration partners. The importance of cultural knowledge and project-based innovation implies that knowledge exchange in symbolic industries takes place primarily within localized networks (Plum and Hassink 2014, Manniche and Larsen 2013)

While these findings generally hold true on an industry level, micro-level studies stress that there exists strong heterogeneity between firms in the same industry (Srholec and Verspagen 2012). Firms in one industry may rely on different competencies and specialise into different activities. Also, similar firms can specialise on different knowledge bases to serve different clients (see, for instance, Pina and Tether 2016 on knowledge intensive business services). In fact, combinations of knowledge bases can occur at the level of the industry and at the level of firms. This argument has been advanced in recent studies on knowledge base combinations (Grillitsch, Martin, and Srholec 2016, Manniche, Moodysson, and Testa 2016). These studies indicate that even though analytical, synthetic and symbolic knowledge are distinct ontological categories, they are hardly employed exclusively and detached from other modes of innovation. 
In fact, innovations are often the result of diverse knowledge inputs that are combined in the innovation process. These combinatorial knowledge dynamics call for more nuanced studies on knowledge networks and the involved knowledge bases.

\subsection{Knowledge sourcing mechanisms - collaboration, mobility and monitoring}

The notion of knowledge bases raises the question how and from where firms access and combine new knowledge. Early work on knowledge spillover had the tendency to treat knowledge as freely roaming in the air (e.g. Audretsch and Feldman 1996), while more recent studies acknowledge that knowledge is hardly ever transferred out of pure coincidence (Moodysson 2008, Belussi and Sedita 2012). In fact, knowledge sourcing typically requires a dedicated effort, alongside with the necessary absorptive capacity to make use of that knowledge (Cohen and Levinthal 1990). In order to acquire new knowledge, firms use a number of knowledge sourcing mechanisms and engage into different types of networks. Belussi and Sedita (2012), for example, distinguish between emergent and deliberate knowledge structures. The first constitutes spontaneous and non-deliberate forms of social interaction such as social netwoks and communities of practice, while the latter include business networks and formal R\&D linkages through which firms gain access to specialized complementary capabilities and/or new scientific knowledge.

A commonly observed type of knowledge relation is inter-organizational collaboration, where firms engage into reciprocal relationships which lead to bidirectional flows of knowledge (e.g. Fitjar and Rodríguez-Pose 2013, Herstad, Aslesen, and Ebersberger 2014, Chaminade and Plechero 2015). Collaboration networks can be of formal nature as in the case of contract-based R\&D partnerships, strategic alliances or joint ventures (e.g. Balland, De Vaan, and Boschma 2013, Jakobsen and Lorentzen 2015), or they can be of informal nature, for instance in the form of social relationships or professional communities (e.g. Grabher and Ibert 2006, Huber 2012, 
Lorenzen and Mudambi 2013). They manifest on the organizational level, but are often mediated on the individual level through inter-personal relations. Huber (2012) shows that even in R\&D intensive industries, important forms of knowledge exchange do not only occur through formal collaborations, but through personal networks between skilled workers. Geographical proximity and face-to-face interactions facilitate the formation of personal relationships that subsequently lead to innovation-related collaboration between firms. In cultural and creative industries, knowledge is often exchanged in a dynamic interplay between formal project collaboration and informal social networking (Garmann Johnsen 2011). Even though the regional level plays a vital role in creative industries (Plum and Hassink 2014), collaboration is not limited to spatial proximity, but can span over long distances (Vang and Chaminade 2007, van Egeraat, O'Riain, and Kerr 2013, Manniche and Larsen 2013).

A second type of knowledge sourcing mechanism is labour mobility, that is, the movement of skilled individuals between organizations (Herstad, Sandven, and Ebersberger 2015, Trippl 2013). As important forms of knowledge are tacit and embodied into people, hiring skilled labour is a natural way to bring new competences to the firm. Studies that deal with the impact of labour flows on firm performance show that recruitment from the higher education system as well as from related industries in the region has a positive effect on the innovation capacity of firms (Herstad, Sandven, and Ebersberger 2015). In order to gain a positive effect on firm performance, skill portfolios of newly recruited employees should be related to the existing knowledge base of a firm, while too little, but also too much skill relatedness can have a negative impact (Boschma, Eriksson, and Lindgren 2009). In line with this, Timmermans and Boschma (2014) find that the effect of labour mobility on firm performance depends on the relatedness between the skills of current and newly hired staff. Building on the method of Neffke and Henning (2013), they find that the inflow of related skills impacts plant performance positively, while the inflow of similar skills has a negative effect. Moreover, they find that this 
effect depends on whether new employees are recruited from the same region or from other regions, whereby inter-regional mobility has a particularly positive effect. A number of studies trace the location decisions of skilled labour (Alfken 2015, Niedomysl and Hansen 2010, Hansen and Niedomysl 2009, Alfken, Broekel, and Sternberg 2015). Despite Florida's (2002) argument that skilled labour tends to move to places with attractive living conditions, empirical evidence shows that migration decisions depend primarily on job conditions in a region (Alfken, Broekel, and Sternberg 2015, Niedomysl and Hansen 2010). This even holds for creative professions, which, according to Frederiksen and Sedita (2011), are characterised by greater job mobility than other occupations. Alfken (2015) shows that inter-regional mobility is high for creative professions in an early career phase, while geographical mobility decreases in later phases of career development. These studies show that irrespective of the type of industry, labour mobility primarily depends on the job prospects in a region as well as on the life and career stage of the labour force.

A third type of knowledge sourcing channel is monitoring. Firms source new knowledge also through monitoring of innovation activities carried out by other organizations (Malmberg and Maskell 2002, Martin and Moodysson 2013). Monitoring can include systematic market research, the observation of customers, suppliers and competitors over various media channels (e.g. websites, social media or specialised magazines), or the attendance at trade or design fairs and exhibitions. Some monitoring activities are facilitated by spatial proximity, while others are hardly bound to specific places. Bathelt and Gibson (2013) show that firms gather in trade fairs in order to monitor competitors and partners and to source knowledge about the latest technological developments. Trade fairs can create temporary forms of proximity (Torre 2008), which, if recurrent, can lead to more stable knowledge linkages over far geographical distance. Grabher and Ibert (2014) show that knowledge sourcing can take place via online platforms, in which interaction is mediated by virtual communication tools, and where economically useful 
knowledge is created and exchanged in absence of physical proximity. Martin and Moodysson (2013) argue that trade fairs and specialised magazines are important monitoring mechanisms for symbolic and synthetic industries, while analytical industries tend to use scientific journals and systematic investigations to learn about other firm's innovation activities. Furthermore, organization studies researchers (e.g. Gioia and Manz 1985, Huber 1991) and industrial district theorists (Boari, Fioretti, and Odorici 2008, Belussi 2010) use the notion of "vicarious learning" when referring to non-collaborative organisational learning, for example, when companies in clusters learn from rival firms and adapt their business strategies.

We argue in this paper that firms can acquire and combine new knowledge through multiple channels, each of which has different sensitivities to geographical distance. Even though the local level is considered as key arena for knowledge sourcing in particular for symbolic industries, the importance of local knowledge sourcing varies between knowledge channels. Collaboration networks are expected to be highly localised, in particular for flexible and project-based industries such as new media. The same is expected for the mobility of skilled labour, at least in regions with a decent job market and for firms that intend to hire skilled staff with job experience. Monitoring, in contrast, is expected to be less bound to spatial proximity, as firms can make use of temporary or organized proximities to overcome spatial distance.

\subsection{Knowledge sourcing, knowledge bases and proximity dimensions}

In order to investigate the role of geography for different knowledge sourcing channels, it is necessary to elaborate more on the notion of proximity (Torre and Gilly 2000, Boschma 2005, Knoben and Oerlemans 2006). Proximity should be seen as multidimensional concept that goes beyond mere physical co-location. Instead, it should be understood through social and contextual factors (Sayer 1992, Morgan 2004). Knowledge exchange tends to be facilitated by short geographical distance, while at the same time, physical proximity alone is not enough to 
allow for fruitful knowledge exchange, if not accompanied with other forms of proximity. Building on the French Proximity School (Torre and Gilly 2000; Torre and Rallet 2005), Boschma (2005) distinguishes between five proximity dimensions, namely cognitive, organizational, institutional, social and geographical (i.e. physical) proximity. These dimensions can overlap, but also substitute one another (Menzel 2015, Hansen 2015).

Cognitive proximity refers to the idea that firms are more likely to exchange knowledge with organizations that are cognitively similar, that is, share similar routines and problem solving strategies. Successful knowledge transfer requires absorptive capacity to identify, interpret and exploit the new knowledge (Cohen and Levinthal 1990), which is most likely to be present in firms with similar knowledge base (Mattes 2012). Boschma $(2005,63)$ argues that "as a rule, firms search in close proximity to their existing knowledge base, which provides opportunities and sets constraints for further improvement". If cognitive proximity is too small, the cooperating actors will not understand each other, which impedes effective knowledge transfer. But if cognitive proximity is too high, knowledge exchange will not lead to any novel recombinations. Thus, the right degree of cognitive proximity and distance is essential for fruitful collaborations (Nooteboom et al. 2007).

While cognitive proximity is probably the most important prerequisite for fruitful knowledge exchange, also organizational, institutional and social proximity plays a role. Organizational proximity commonly refers to the degree of firm internalization (Mattes 2012). A high organizational proximity implies that firms follow similar organizational logics or even belong to the same company group. For example, organizational proximity between private firms and public organizations would be very small, as they follow different organizational rationalities, while it would be high for firms with similar business structure (e.g. same type of small firm or new venture). Institutional proximity refers to formal institutions such as laws, rules and regulations, as well as to informal ones, that is, norms, values and routines (North 1990). 
Institutional proximity is what comes closest to the understanding of space in the literature on regional innovation systems (RIS), in which most arguments focus on how regional institutional settings create opportunities for innovation and knowledge exchange (Cooke 2002, Asheim and Gertler 2005). Social proximity refers to the social embeddedness of actors in terms of friendship, kinship, and common experience. It is the result of shared personality traits, personal interaction and a sense of familiarity between individuals. More than any other proximity dimension, social proximity relies on trust that is built up through repeated interactions over a long period of time (Boschma 2005).

These different dimensions of proximity allow a more fine-grained perspective on the role of space for knowledge exchange and innovation. They lead to a number of research hypotheses related to the question how and from where firms acquire and combine different types of knowledge through different network channels.

- First, one can expect most knowledge exchange to take place locally, as the region is the area where geographical and institutional (and often also social) proximity is present. This is particularly important for collaboration and mobility, and less for monitoring, which does not necessarily entail inter-personal relations.

- Second, one can expect knowledge base combinations, i.e. knowledge flows between firms with different knowledge base, to take place primarily within the region, as institutional and social proximity can compensate for a lack of cognitive proximity.

- And third, one can expect knowledge exchange between firms with similar knowledge base to be less bound to the local level, as cognitive (and organizational) proximity can substitute for other types of proximity. 
These theoretical considerations are investigated based on a case study on the media cluster in Bergen, Norway. As we will show, this cluster is not dominated by one knowledge base only, but by a combination of synthetic and symbolic knowledge bases.

\section{Research design: A case study on the media industry in Bergen}

The media industry covers a range of activities, including the generation of media content (news, music, film, etc.) and technical solutions for broadcasting and displaying media content on various devices (TVs, mobile phones, tablet computers, etc.). This paper examines how, and from where, media firms acquire and combine knowledge for their innovation activities. As innovation is a complex social phenomenon, a case study is well suited as methodical approach to the empirical inquire, and corresponds to the preferred method of empirical inquiry within the field of regional innovation research (Asheim, Coenen, and Moodysson 2015). In the following, an introduction to the media industry in general and the media industry in Bergen in particular, is provided.

\subsection{The media industry between content and technology}

The key focus of the media industry is to produce and distribute media content. In recent years, technological progress opened new ways for digital communication. The ICT revolution has led to new applications and services, and today, consumers retrieve media content on a range of digital devices. Furthermore, consumers take a more and more active role in tailoring their media consumption to personal interests and preferences. As a consequence, media firms have to be present on a range of different media platforms in order to reach their customers (Groot Kormelink and Costera Meijer 2014). 
This new development is a challenge to traditional media firms. In order to be successful on the market, firms need to display media content in multiple ways and on various platforms, which requires new technical competencies (Turow 2005, Groot Kormelink and Costera Meijer 2014). This development has led to an increased specialisation among media firms. Today, the media industry consists largely of companies that either specialise on the production of media content or on the provision of technological solutions related to media (Jenkins 2006, Currah 2009).

As it has been stressed in the literature, ICT and software development are dominated by synthetic knowledge (Tödtling and Grillitsch 2015) whereas the creation of media content relies mostly on symbolic knowledge (Asheim 2007, Martin and Moodysson 2011). To the extent that firms specialise on either media content or technology, they also differ in the type of knowledge base that is critical for innovation. Even though most media content providers also hold technical competences in-house, they innovate primarily based on symbolic knowledge. In contrast, media technology providers need an understanding of the creation of media content, but innovate mostly based on synthetic knowledge. In order to be active in the same industry, all firms need to possess or have access to both synthetic and symbolic knowledge, which they either hold in-house or source from other firms through different network channels (Currah 2009).

\subsection{The media industry in Bergen}

Bergen is the second-largest city in Norway with around 275.000 inhabitants. The region has economic strongholds in the energy, the maritime and the marine sectors, as well as growing industries such as culture and media. The city serve as a knowledge hub for the western part of Norway, hosting a large and traditional university, nine colleges, ten research institutes and four official clusters organised within the cluster program of Innovation Norway. Together with its surrounding region, Bergen can be seen as a thick and diversified RIS, with a strong research 
and higher education system and policy makers that are actively engaged in innovation-based regional development (Isaksen and Trippl 2016). The local media industry took off in 1992 when national government decided to locate the headquarters of Norway's second public broadcasting channel (TV2) to Bergen. This spurred new entrepreneurial activities and the media industry started to grow. In 1993, the first policy initiative to stimulate collaboration and knowledge transfer between media firms was established under the name of Bergen Media City. During the next decades, the size and scope of the media cluster increased continuously. In 2014, the initiative was awarded the second highest cluster status in Norway, Norwegian Centre of Expertise $\mathrm{NCE}^{2}$, and renamed to NCE Media. This resulted in more public funding and expert services tailored towards increased value creation, collaboration with international partners, and interaction between firms and R\&D organisations.

\subsection{Method and data collection}

Due the diverse nature of the industry, the media cluster in Bergen is not easy to delimit. It consists of a variety of firms, of which some can be considered as pure media firms, while others serve multiple markets. Some technology-based firms, for example, are pure media software developers while others direct only parts of their business to the media industry. This raises some methodical concerns. Firstly, as the industry boundaries are blurry, it is not possible to identify media firms from any conventional business classification scheme. Secondly, as some relevant firms are not fully committed to the media sector, not all knowledge relations are maintained for media-related activities. And thirdly, there is a potential bias related to the policy support structure. As NCE Media facilitates networking between its members, knowledge sourcing activities can be expected to vary systematically between member and non-member

\footnotetext{
${ }^{2}$ For more information on cluster policy instruments in Norway, see Innovation Norway (2015).
} 
organisations. Furthermore, it is also likely that long-time members are systematically distinct from new members.

In order to minimize these potential biases, this study focuses on commercial firms that have been members of NCE Media for at least one year. Accordingly, only firms that consider themselves as part of the media industry are included in the analysis. A list of member organisations provided by the cluster management included 37 qualified member organisations, from which 22 commercial firms were identified (besides 15 public and non-profit organisations). Data was collected in May-June 2015 using structured interviews with firm representatives from all 22 firms. Meetings were arranged with the CEO or a member of the top-management team. The interview data was complemented with document studies on policy reports, company websites and other publicly available information. An overview of the interviewed firms is provided in Table 1.

Table 1: Overview of interviewed firms

\begin{tabular}{lll}
\hline Basic firm information & Number of firms & \% of firms \\
\hline Located in Bergen & 22 & 100.0 \\
Originates from Bergen & 21 & 95.5 \\
Part of a corporation & 15 & 68.2 \\
Age $>5$ years & 18 & 81.8 \\
Age $>15$ years & 11 & 50.0 \\
Size $<10$ employees & 8 & 36.4 \\
Size $<100$ employees & 17 & 77.3 \\
Classifies itself as media content provider & 14 & 63.6 \\
Classifies itself as media technology provider & 8 & 36.4 \\
\hline Total & $\mathbf{2 2}$ & $\mathbf{1 0 0 . 0}$ \\
\hline
\end{tabular}

Source: own data

A roster-recall method was applied to collected relational data on inter-organisational knowledge flows (for a discussion on the method, see Giuliani and Pietrobelli 2014). The interview partners were provided a list (i.e. roster) of potentially relevant organisations, 
including commercial firms, education and research organisations, policy support organisations and industry relevant non-profit organisations (74 in total). Connected to the roster, the interviewees were asked to fill in additional regional, national or international organisations relevant to their innovation activities that were not mentioned in the list (i.e. recall). Relational data was illustrated and analysed using Social Network Analysis (SNA) and descriptive statistics.

The relational data includes information on the location and the type of contact partners. The first classifies all actors in regional, national, European, and global partners. The latter divides all actors into content providers, technology providers, other types of firms, universities and R\&D organisations, policy support organisations, and other public organisations. The interviewees specified the name and location of their contact partners as well as their importance. Company websites and business databases were used by the authors to validate and complement the names, locations and types of partners listed by the interviewees.

\section{Empirical Analysis: Knowledge Flows and Networks in the Bergen media cluster}

The following analysis explores the geography and organisation of knowledge networks in the media cluster in Bergen. We investigate how firms acquire and combine various types of knowledge through different network channels and from different geographical scales. We begin the analysis by identifying the types of knowledge that firms use in their innovation processes.

\subsection{Combinatorial knowledge bases}

To identify the knowledge bases involved in innovation, two questions were asked to the firm representatives. First, to rate (from 1-5) the importance of scientific, engineering and arts-based 
skills and competencies for the competitiveness of their firm. Second, to group their skilled employees into broadly defined education profiles, reflecting the three knowledge bases.

Table 2: The importance of different skills and competencies for innovation

\begin{tabular}{lccc}
\hline Firm type & Scientific skills & Engineering skills & Arts-based skills \\
\hline Content provider & 1,43 & 4,14 & 4,64 \\
Technology provider & 2,65 & 4,50 & 4,37 \\
\hline Total & $\mathbf{1 , 8 6}$ & $\mathbf{4 , 2 7}$ & $\mathbf{4 , 5 5}$
\end{tabular}

Note: Importance at a scale from 1-5, where 1 is not important and 5 is very important. Average values.

Source: own data

Table 2 shows that both symbolic and synthetic knowledge are regarded as vital for innovation by all firms. This holds equally true for media content providers and technology providers. Analytical knowledge is regarded as far less important, in particular by content providers who attribute almost no relevance to science-based competencies. This demonstrates that firms in the media industry build on a combination of symbolic and synthetic knowledge for their innovation activities. However, the extent to which firms hold symbolic or synthetic knowledge in house or source it from outside varies considerably between content and technology providers.

Table 3: Formal education profile among media firms in Bergen

\begin{tabular}{lrccc}
\hline Firm type & $\begin{array}{c}\text { Scientific } \\
\text { education }\end{array}$ & $\begin{array}{l}\text { Engineering } \\
\text { education }\end{array}$ & $\begin{array}{l}\text { Arts-based } \\
\text { education }\end{array}$ & $\begin{array}{c}\text { Other types of } \\
\text { education }\end{array}$ \\
\hline Content provider & $4,0 \%$ & $19,1 \%$ & $50,5 \%$ & $26,4 \%$ \\
Technology provider & $0,8 \%$ & $75,7 \%$ & $17,4 \%$ & $6,1 \%$ \\
\hline Total & $\mathbf{2 , 7} \%$ & $\mathbf{4 1 , 9 \%}$ & $\mathbf{3 7 , 2} \%$ & $\mathbf{1 8 , 2} \%$ \\
\hline
\end{tabular}

Note: The relative number of staff holding a Bachelor degree or above, divided into main education groups.

Source: own data

Table 3 shows the education profiles of employees, again divided between content and technology providers. All firms have personnel with engineering and creative educational 
background, however, a clear difference between the two subgroups can be observed. While content providers employ mostly people with background in creative fields $(50,5 \%)$ and less people with engineering-based skills $(19,1 \%)$, technology providers clearly favour engineeringbased skills $(75,7 \%)$ over creative skills $(17,4 \%)$. This finding is essential as it shows that a specialisation in firm-internal knowledge bases can be observed, in which firms focus either on symbolic or on synthetic knowledge. Thus, media firms combine different knowledge bases in their innovation process, but specialise in one knowledge base in their firm-internal education profiles.

The following analysis deals with sourcing of firm-external knowledge through collaboration, monitoring and mobility.

\subsection{Collaborative knowledge sourcing}

The first type of knowledge sourcing mechanism is collaboration, that is, interactive knowledge exchange between firms and other organisations. The firms were asked with whom they have collaborated and exchanged knowledge related to innovation during the last three years.

Table 4: Average number of collaboration partners

\begin{tabular}{|c|c|c|c|c|c|c|}
\hline \multirow{2}{*}{ Interviewed firm } & \multirow{2}{*}{ Contact partner } & \multicolumn{5}{|c|}{ Spatial dimension } \\
\hline & & Regional & National & European & Global & SUM \\
\hline Content provider $n=14$ & Content provider & 4.64 & 1.07 & 0.21 & 0.29 & 6.21 \\
\hline \multirow[t]{2}{*}{ Tech provider $n=8$} & Content provider & 4.25 & 0.38 & 0.88 & 0.50 & 6.00 \\
\hline & $P$ value $=$ & 0.8033 & 0.2052 & 0.2160 & 0.4187 & 0.9150 \\
\hline Content provider $n=14$ & Tech provider & 2.43 & 0.07 & 0.21 & 0.21 & 2.93 \\
\hline \multirow[t]{3}{*}{ Tech provider $\mathrm{n}=8$} & Tech provider & 4.38 & 1.13 & 0.38 & 0.75 & 6.63 \\
\hline & $\mathrm{P}$ value $=$ & $0.0873(*)$ & 0.0096 & 0.6479 & 0.2816 & $0.017(* *)$ \\
\hline & & & $(* * *)$ & & & \\
\hline Content provider $n=14$ & Other firms & 1.00 & 0.07 & 0.07 & - & 1.14 \\
\hline \multirow[t]{2}{*}{ Tech provider $n=8$} & Other firms & 1.25 & 0.75 & - & - & 2.00 \\
\hline & $\mathrm{P}$ value $=$ & 0.5742 & $0.0286(* *)$ & 0.4632 & - & 0.1744 \\
\hline
\end{tabular}




\begin{tabular}{|c|c|c|c|c|c|c|}
\hline \multirow{2}{*}{ Interviewed firm } & \multirow{2}{*}{ Contact partner } & \multicolumn{5}{|c|}{ Spatial dimension } \\
\hline & & Regional & National & European & Global & SUM \\
\hline Content provider $\mathrm{n}=14$ & Univ. and R\&D'S & 1.14 & 0.14 & 0.07 & - & 1.36 \\
\hline \multirow[t]{3}{*}{ Tech provider $n=8$} & Univ. and R\&D`s & 3.00 & 0.25 & 0.13 & - & 3.38 \\
\hline & $\mathrm{P}$ value $=$ & 0.0063 & 0.6410 & 0,6916 & - & $0.0047(* * *$ \\
\hline & & $(* * *)$ & & & & ) \\
\hline Content provider $n=14$ & Policy support org`s & 2.07 & 0.14 & - & - & 2.21 \\
\hline \multirow[t]{2}{*}{ Tech provider $n=8$} & Policy support org`s & 2.00 & - & - & - & 2.00 \\
\hline & $\mathrm{P}$ value $=$ & 0.9261 & - & - & - & 0.7964 \\
\hline Content provider $n=14$ & Other Public org`s & 0.43 & - & - & - & 0.43 \\
\hline \multirow[t]{2}{*}{ Tech provider $\mathrm{n}=8$} & Other Public org`s & - & 0.13 & - & - & 0.13 \\
\hline & $\mathrm{P}$ value $=$ & 0,284 & - & - & - & 0.4569 \\
\hline Content provider $n=14$ & Total & 11.71 & 1.50 & 0.57 & 0.50 & 14.29 \\
\hline \multirow[t]{2}{*}{ Tech provider $n=8$} & Total & 14.88 & 2.63 & 1.38 & 1.25 & 20.13 \\
\hline & $\mathrm{P}$ value $=$ & 0.3490 & 0.1819 & 0.2523 & 0.2827 & 0.1483 \\
\hline
\end{tabular}

Note: $\left(^{*}\right)$ significant at a 10 percent level, $\left(^{* *}\right)$ significant at a 5 percent level, $\left(^{* * *}\right)$ significant at a 1 percent level. An unpaired t-test has been used to test the difference between the mean values of the two groups. Source: own data

Table 4 provides an overview of the number of collaboration partners identified by the interviewed firms.

The first significant finding relates to knowledge flows between the two identified groups of firms, namely content and technology providers. When it comes to collaborations with technology providers, significant differences between the two groups can be observed $(\mathrm{P}=0.017)$. While the interviewed content providers list an average of 2.93 technology providers as contact partners, the corresponding number for the interviewed technology providers is 6.63 . It is reasonable to argue that technology providers are valuable collaboration partners particularly for other technology providers, as they share similar knowledge bases. However, the result becomes striking when looking at collaboration with content providers. Following the same logic, one would expect content providers to connect primarily to other content providers. 
This is, however, not the case. Collaboration with content providers is equally important for both groups of firms $(\mathrm{P}=0.915)$. Content providers are overall the most preferred collaboration partners, which points at the key role of symbolic knowledge for the media cluster.

Secondly, the table show that science- and technology-based knowledge enters the cluster mainly through technology providers. This becomes apparent as technology providers are significantly more active in collaborating with universities and other R\&D organisations than content providers $(\mathrm{P}=0.0047)$. Furthermore, the data shows that the region is by far the most frequent geographical level for collaborations with universities and other R\&D organisations. This can be explained by the fact that technology providers in the cluster have a strong focus on tailor-made solutions for the local market, and less on mass-production for global markets. Such tailor-made solutions demand close and continuous interaction, which is facilitated by geographical proximity.

A third finding is the importance of geographical proximity. Comparing the number of regional and non-regional collaboration partners reveals that $80 \%$ of all collaborations take place within in the Bergen region. This shows that the region is by far the most important arena for collaboration and knowledge exchange for firms in the cluster.

In addition to these statistically significant findings, also the absence of differences between content providers and technology providers is worth mentioning. Since prior studies have argued that symbolic knowledge is more localized than synthetic knowledge (e.g. Asheim, Boschma, and Cooke 2011, Martin and Moodysson 2013), one would expect to find geographical different preferences between the two groups of firms. However, no such differences can be observed. In fact, both groups of firms prioritize local knowledge sources over distant ones, irrespective of the type of knowledge base of the collaboration partner. The absence of geographical preferences between symbolic and synthetic firms can be explained by 
the fact that the media cluster in Bergen is dominated by two knowledge bases (in contrast to existing studies that argue that clusters have one critical knowledge base only, see e.g. Tödtling, Asheim, and Boschma 2013). As the media cluster in Bergen relies on two different knowledge bases, geographical and institutional proximity are particularly important, as they can compensate for a low degree of cognitive proximity between partners (Hansen 2015, Menzel 2015, Mattes 2012).

Figure 2: Mobility network

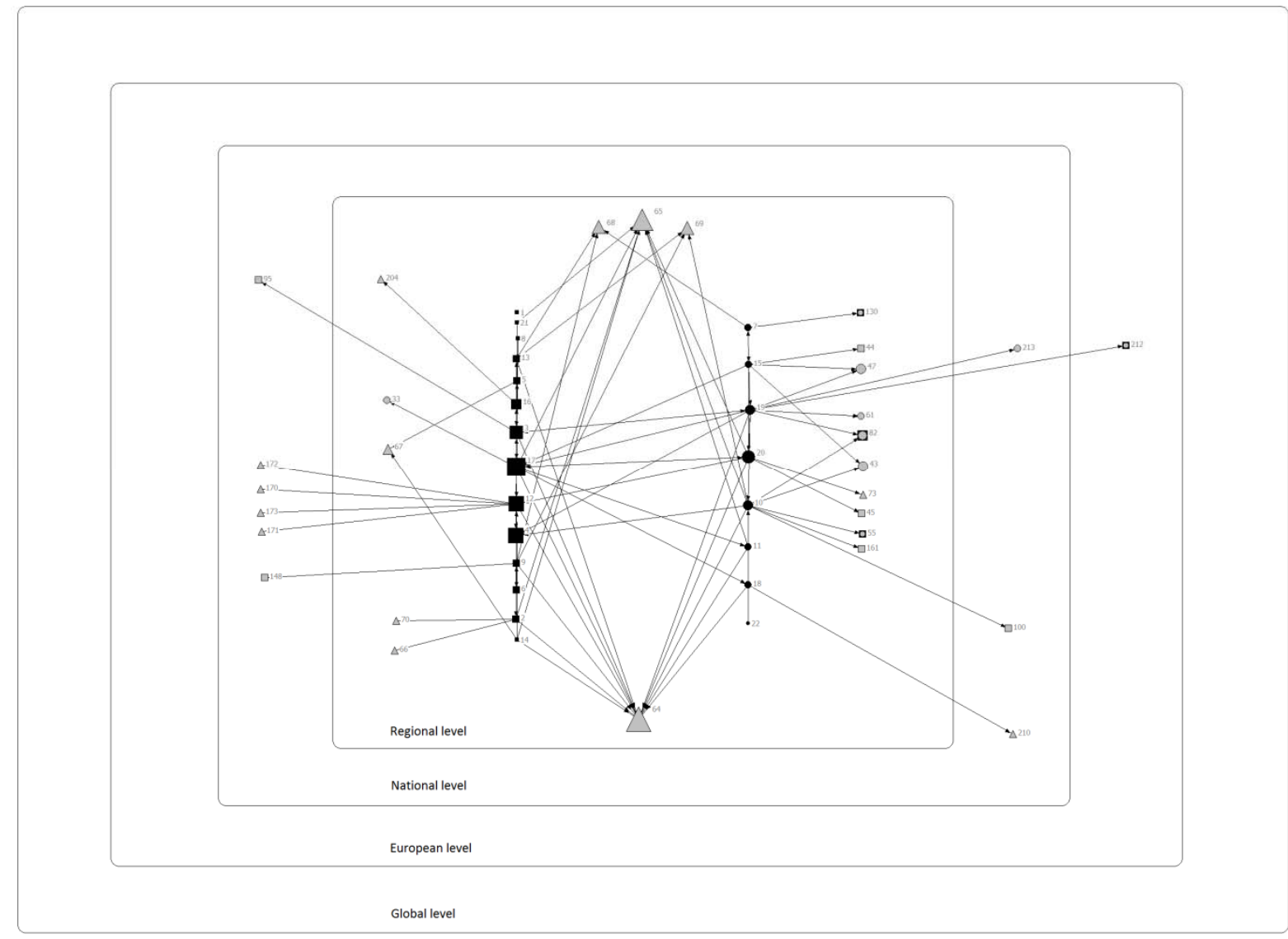

Note: The node shape reflects the type of organization (square = content provider; circle = technology provider; circle-in-boxes = other types of firms; up-triangles = universities and $R \& D$ organisations; diamonds = policy support organizations; integrated triangles = other public organizations). The node colour displays whether the organization has been interviewed (black = interviewed firm; grey = contact partners). The node size reflects its relative importance in the networks (in-degree centrality). Source: own draft

Figure 1 illustrates the collaboration network. Among the interviewed firms, the most active collaborators are two content providers and two technology providers, namely the dominant 
local newspaper (ID 3), a national broadcasting company (ID 17), a locally based global technology provider (ID 20) and a local office of a national technology firm (ID 10). These firms connect similarly to content and technology providers, and, by virtue of their position in the network, are important knowledge hubs that link synthetic and symbolic knowledge. The most frequently mentioned collaboration partners are the local university (ID 64), followed by other local R\&D organizations and policy support organizations.

When it comes to extra-regional collaboration, an online TV platform producer (ID 19), a firm specialized in interactive TV (ID 15) and a media tech company (ID 10) are the most outreaching technology providers. The most outreaching content providers are a video game developer (ID 14) and a music company (ID 1). These companies are important as they provide the cluster with extra-regional knowledge.

\subsection{Knowledge sourcing through mobility}

The second knowledge sourcing channel is mobility. By hiring skilled labour, firms gain access to tacit knowledge and can both upgrade or diversify their firm-internal knowledge base.

Table 5: Average number of mobility sources

\begin{tabular}{|c|c|c|c|c|c|c|}
\hline \multirow{2}{*}{ Interviewed firm } & \multirow{2}{*}{ Contact partner } & \multicolumn{5}{|c|}{ Spatial dimension } \\
\hline & & Regional & National & European & Global & SUM \\
\hline Content provider $n=14$ & Content provider & 1.21 & 0.14 & - & - & 1.36 \\
\hline \multirow[t]{2}{*}{ Tech provider $\mathrm{n}=8$} & Content provider & 1.25 & 0.25 & - & - & 1.50 \\
\hline & $\mathrm{P}$ value $=$ & 0.9419 & 0.5533 & - & - & 0.7990 \\
\hline Content provider $n=14$ & Tech provider & 0.36 & - & - & - & 0.36 \\
\hline \multirow[t]{2}{*}{ Tech provider $n=8$} & Tech provider & 1.50 & 0.13 & - & - & 1.63 \\
\hline & $\mathrm{P}$ value $=$ & $0.0876(*)$ & - & - & - & $0.0770(*)$ \\
\hline Content provider $n=14$ & Univ. and R\&D'S & 1,43 & 0.29 & - & - & 1.71 \\
\hline \multirow[t]{2}{*}{ Tech provider $\mathrm{n}=8$} & Univ. and R\&D`s & 1,38 & 0.13 & - & - & 1.50 \\
\hline & $\mathrm{P}$ value $=$ & 0.9263 & 0.6870 & - & - & 0.7502 \\
\hline
\end{tabular}




\begin{tabular}{|c|c|c|c|c|c|c|}
\hline \multirow{2}{*}{ Interviewed firm } & \multirow{2}{*}{ Contact partner } & \multicolumn{5}{|c|}{ Spatial dimension } \\
\hline & & Regional & National & European & Global & SUM \\
\hline Content provider $\mathrm{n}=14$ & Other types of firms & - & - & - & - & - \\
\hline \multirow[t]{2}{*}{ Tech provider $n=8$} & Other types of firms & 0.50 & - & 0.13 & - & 0.63 \\
\hline & $\mathrm{P}$ value $=$ & $0.0202(* *)$ & - & - & - & $0.0171(* *)$ \\
\hline Content provider $n=14$ & Total & 3,00 & 0.43 & - & - & 3.43 \\
\hline \multirow[t]{2}{*}{ Tech provider $\mathrm{n}=8$} & Total & 4,63 & 0.50 & 0.13 & - & 5.25 \\
\hline & $\mathrm{P}$ value $=$ & 0.1657 & 0.8718 & - & - & 0.1629 \\
\hline
\end{tabular}

Note: $\left({ }^{*}\right)$ significant at a 10 percent level, $\left({ }^{* *}\right)$ significant at a 5 percent level, $\left({ }^{* * *}\right)$ significant at a 1 percent level. An unpaired t-test has been used to test the difference between the mean values of the two groups.

Source: own data

Table 5 displays labour mobility patterns. The firm representatives were asked from where and whom they hired during the last three years. When interpreting the results, recent developments in the media industry should be kept in mind. While the demand for media technology has been growing, traditional media content firms such as newspapers and publishing companies have been under efficiency pressures and have been outsourcing and downsizing (Currah 2009). Consequently, one can expect technology providers to be more active in hiring new employees than content providers.

In line with that, the table shows that the average number of mobility sources is higher for synthetic firms (5.25) than for symbolic firms (3.43). Furthermore, it displays an interesting unequal distribution of mobility sources. If the origin firm of a newly hired employee is a technology provider, the recruiting firm is also most likely a technology provider, and not a content provider $(\mathrm{P}=0.0876)$. However, if the origin firm is a content provider, the difference is not significant. This is in line with the findings for the collaboration network, namely that Bergen media cluster favours symbolic knowledge over technological knowledge.

Finally, and addressing the geographical dimension, we find that the most important recruitment area is the Bergen region $(80 \%)$, followed by other parts of Norway $(11 \%)$, whereas 
international requirement is almost non-existent (1\%). This confirms that the media industry is highly localised, in particular when it comes to hiring skilled labour (Alfken 2015, Alfken, Broekel, and Sternberg 2015). Thus, even more than for collaboration, geographical proximity is key for knowledge sourcing through labour mobility. The success of media firms heavily depends on the access to a local pool of skilled labour.

Figure 2: Mobility network

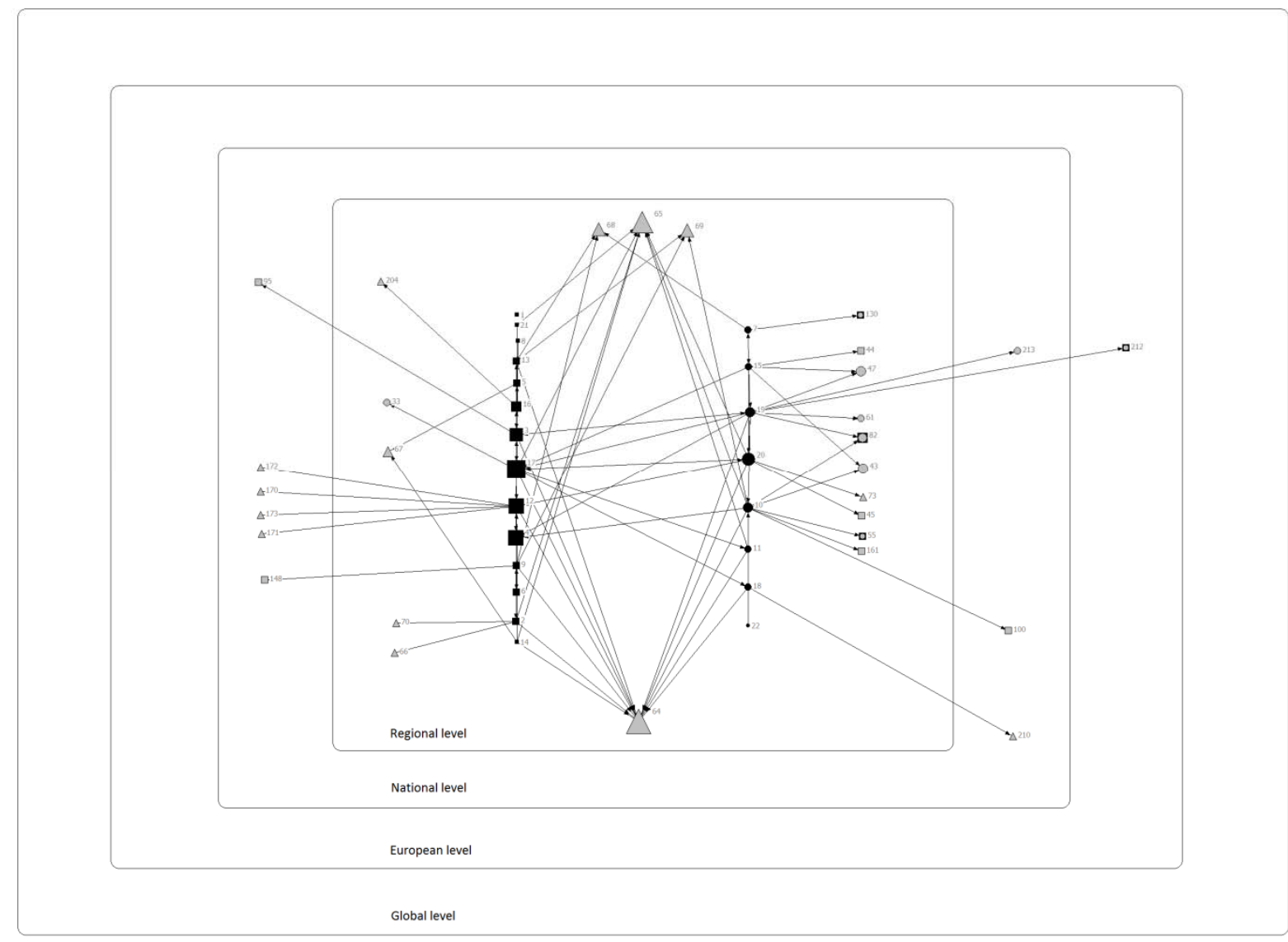

Note: The node shape reflects the type of organization (square = content provider; circle = technology provider; circle-in-boxes $=$ other types of firms; up-triangles $=$ universities and $R \& D$ organisations; diamonds = policy support organizations; integrated triangles = other public organizations). The node colour displays whether the organization has been interviewed (black = interviewed firm; grey = contact partners). The node size reflects its relative importance in the networks (in-degree centrality). Source: own draft

Figure 2 visualizes the mobility network. The second national broadcasters (ID 17) and a global technology provider (ID 20) stand out as the most frequently mentioned source of 
skilled labour. Together with the local newspaper (ID 3), they provide qualified labour to both symbolic and synthetic firms, and constitute an important knowledge hub in the mobility network. Among all content providers, the first national broadcaster (ID 12) is most active in hiring extra-regionally, in particular from the national level, while the second national broadcaster (ID 17) hires mostly locally. Among the technology providers, the online TV platform producer (ID 19) is particular active in recruiting new employees and the only firm hiring from abroad. Among all actors, the local university (ID 64) is the most frequently mentioned source of skilled labour. This underlines the key importance of the local higher education system for the development of the cluster.

\subsection{Knowledge sourcing through monitoring}

The third knowledge sourcing mechanism is monitoring, that is, the observation of innovation activities of other organizations without engaging into direct interaction (Malmberg and Maskell 2002).

Table 6: Average number of monitoring sources

\begin{tabular}{|c|c|c|c|c|c|c|}
\hline \multirow{2}{*}{ Interviewed firm } & \multirow{2}{*}{ Contact partner } & \multicolumn{5}{|c|}{ Spatial dimension } \\
\hline & & Regional & National & European & Global & SUM \\
\hline Content provider $n=14$ & Content provider & 3.79 & 1.43 & 0.57 & 1.14 & 6.93 \\
\hline \multirow{2}{*}{ Tech provider $\mathrm{n}=8$} & Content provider & 6.88 & 0.38 & 0.88 & 0.38 & 8.50 \\
\hline & $P$ value $=$ & $0.0500(* *)$ & 0.1219 & 0.6503 & 0.2935 & 0.4968 \\
\hline Content provider $n=14$ & Tech provider & 2.07 & 0.07 & 0.14 & 0.50 & 2.79 \\
\hline \multirow[t]{2}{*}{ Tech provider $\mathrm{n}=8$} & Tech provider & 4.63 & 1.13 & 0.13 & 0.75 & 6.63 \\
\hline & $\mathrm{P}$ value $=$ & $0.0488(* *)$ & $0.0011(* * *)$ & 0.9120 & 0.7045 & $0.0091(* * *)$ \\
\hline Content provider $n=14$ & Other types of firms & 0.79 & - & 0.07 & - & 0.86 \\
\hline \multirow[t]{2}{*}{ Tech provider $n=8$} & Other types of firms & 1.38 & - & - & 0.25 & 1.63 \\
\hline & $\mathrm{P}$ value $=$ & 0.2593 & - & - & - & 0.2325 \\
\hline Content provider $n=14$ & Univ. and R\&D'S & 1.64 & - & - & - & 1.64 \\
\hline \multirow[t]{2}{*}{ Tech provider $\mathrm{n}=8$} & Univ. and R\&D`s & 2.00 & 0.25 & - & - & 2.25 \\
\hline & $\mathrm{P}$ value $=$ & 0.7037 & & - & - & 0.5274 \\
\hline Content provider $\mathrm{n}=14$ & Policy support org`s & 0.93 & - & - & - & 0.93 \\
\hline
\end{tabular}




\begin{tabular}{|c|c|c|c|c|c|c|}
\hline \multirow{2}{*}{ Interviewed firm } & \multirow{2}{*}{ Contact partner } & \multicolumn{5}{|c|}{ Spatial dimension } \\
\hline & & Regional & National & European & Global & SUM \\
\hline \multirow[t]{2}{*}{ Tech provider $n=8$} & Policy support org`s & 1,75 & - & - & - & 1.75 \\
\hline & $\mathrm{P}$ value $=$ & 0.1962 & - & - & - & 0.1962 \\
\hline Content provider $n=14$ & Average total partners & 9.21 & 1.50 & 0.79 & 1.64 & 13.14 \\
\hline \multirow[t]{2}{*}{ Tech provider $\mathrm{n}=8$} & Average total partners & 16.63 & 1.75 & 1,00 & 1.38 & 20.75 \\
\hline & $\mathrm{P}$ value $=$ & $0.0507(*)$ & 0.7326 & 0.7836 & 0.8259 & $0.0751(*)$ \\
\hline
\end{tabular}

Note: $\left({ }^{*}\right)$ significant at a 10 percent level, $\left({ }^{* *}\right)$ significant at a 5 percent level, $\left({ }^{* * *}\right)$ significant at a 1 percent level. An unpaired t-test has been used to test the difference between the mean values of the two groups.

Source: Own data.

Table 6 displays the average number of monitoring sources indicated by the firms. Based on the number of relations, monitoring can be seen as the most common knowledge sourcing mechanism. The large majority of the monitoring activities occur within the boundaries of the region, which confirms the key role of local knowledge even for non-interactive knowledge sourcing. Compared to collaboration and mobility, however, the monitoring network is less bound to the region and more open towards international knowledge sources.

The observed patterns can be explained with the fact that monitoring is the least formalized and least costly means of knowledge acquisition. Without major social and economic costs, firms can monitor other organisations by attending trade fairs and exhibitions or by joining networking events. Furthermore, firms can use online platforms to screen other firms' innovation undertakings, which make it easy to monitor even over large geographical distance (Grabher and Ibert 2014, Aslesen and Sardo 2016).

Comparing content and technology providers, we find that both groups engage intensively in monitoring. However, technology providers maintain significantly $(\mathrm{P}=0.0751)$ more monitoring relations (average 20,8 respectively 13,1 relations). Similar to collaboration and mobility, technology providers monitor symbolic and synthetic firms to a similar degree (average 8,5 respectively 6,6 relations), while content providers favour symbolic over synthetic firms (average 6,9 respectively 2,8 relations). This once again supports the argument that 
symbolic knowledge is the most important knowledge type in the industry, and that the combination of knowledge bases occurs at an industry level involving firms specializing in different areas of expertise.

Figure 3: Monitoring network

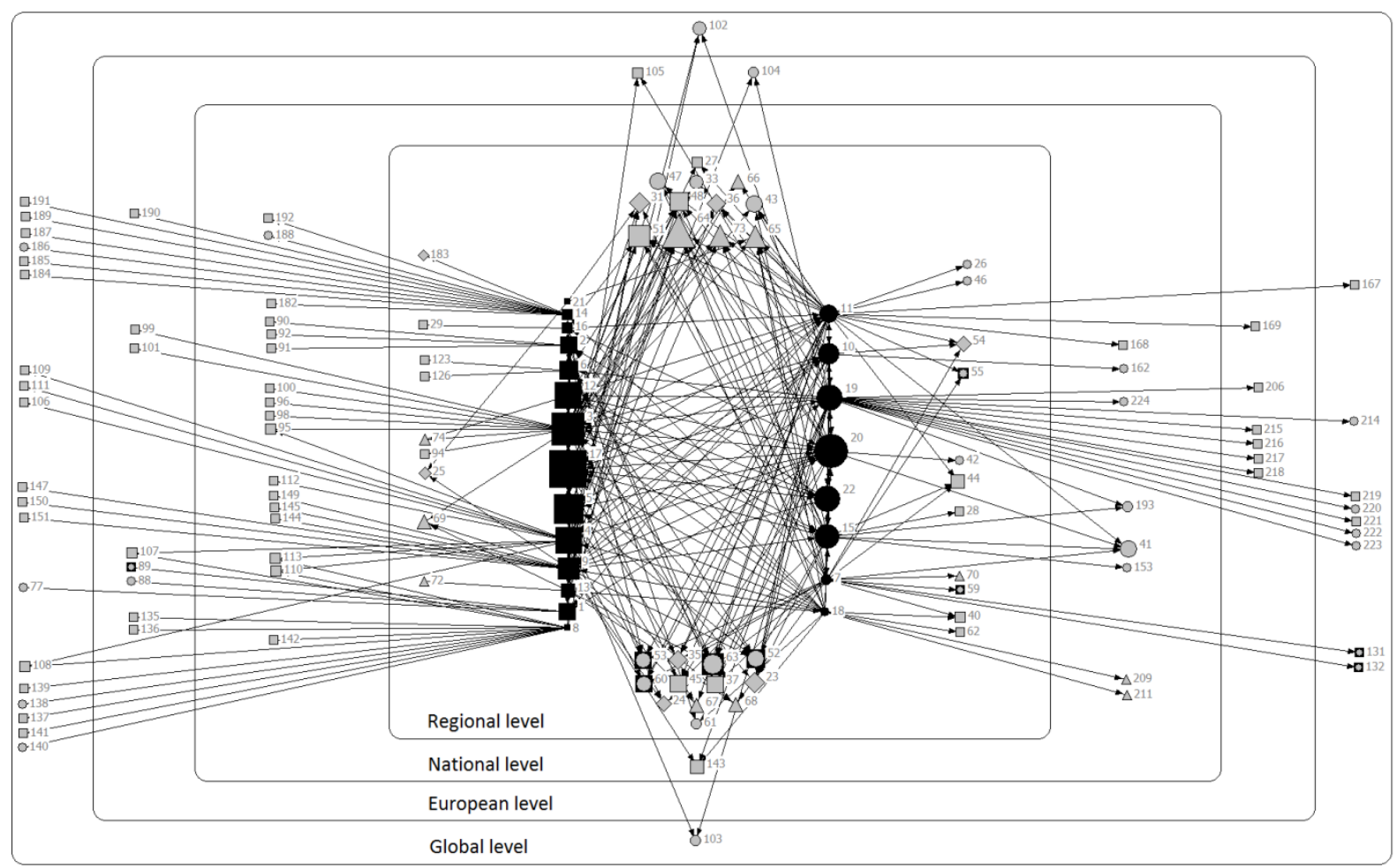

Note: The node shape reflects the type of organization (square = content provider; circle = technology provider; circle-in-boxes = other types of firms; up-triangles = universities and $R \& D$ organisations; diamonds = policy support organizations; integrated triangles = other public organizations). The node colour displays whether the organization has been interviewed (black = interviewed firm; grey = contact partners). The node size reflects its relative importance in the networks (in-degree centrality). Source: own draft

Figure 3 illustrates the monitoring network. As in the previous figures, the second national broadcaster (ID 17) and the global technology provider (ID 20) are the most central knowledge hubs. Holding positions as national market leaders, these two firms are monitored by more than half of the companies in the cluster. Even though they are the most monitored, they are relatively inward-oriented in their own monitoring activities and mention only few partners, most of which are located in the region. Other firms take the position as main pipelines to national and international knowledge sources, notably the online TV platform producer (ID 19), 
a specialised news company (ID 8) and a video game developer (ID 14). This demonstrates that the most central firms in the cluster do not necessarily have the highest international outreach, while in contrast, firm that are less embedded in the core network can be important gatekeepers for accessing global knowledge (Morrison 2008). This can imply a potential danger to the cluster, when novel ideas from outside the region are filtered by gatekeepers and too few reach the core firms. A high degree of regional-mindedness has been found to hinder the innovativeness of firms and can potentially lead to regional lock-in and decline (Fitjar and Rodríguez-Pose 2011, Hassink 2010).

\section{Discussion and conclusion}

This paper contributes to the literature by shedding light on the geography of knowledge sourcing in a cluster that draws on two knowledge bases. We find that symbolic knowledge plays a critical role in the media industry, as it is typical for creative and cultural industries. However, innovation is not only about the generation of media content based on symbolic knowledge, but also about the application and development of media technologies, for which synthetic knowledge is crucial. In view of that, the study shows that media firms often specialise in either symbolic or synthetic knowledge and combine both knowledge bases in the innovation process.

Drawing on this finding, the paper analyses how and from where firms acquire and combine different knowledge. The Bergen region is the prime arena in which knowledge is sourced and combined, even though knowledge exchange also takes place across regional boundaries. In line with previous studies on the role of the local knowledge for creative and cultural industries (Lazzeretti, Boix, and Capone 2008, Martin and Moodysson 2011, Plum and Hassink 2014), we find intense knowledge exchange in the local milieu. However, we find no difference in 
geographical knowledge sourcing preferences between symbolic and synthetic knowledge based firms as one would expect from prior research (Martin and Moodysson 2011). Knowledge sourcing from universities and other R\&D organisations is especially done by technology providers. Thus, technology providers play an important role for the cluster also as they create an access to science-based knowledge (Robertson and Smith 2008).

Contributing to this argument, our study provides a novel and more differentiated perspective on how firms source and combine knowledge from different scales, namely through collaboration, monitoring and mobility. Interestingly, we find that local knowledge sourcing often takes place between firms with different knowledge bases (i.e. content and technology providers). Those firms innovate on different rationales and use different innovation practices, but engage into intensive knowledge exchange with one another. A shared local environment can compensate for a lack of cognitive proximity and enable knowledge exchange even between very different actors. Consequently, the region can be seen as key arena for firms to both strengthen their core competences by exchanging knowledge with cognitively similar organisations, and to diversify and go beyond existing competences by collaborating, monitoring and recruiting from organisations with dissimilar knowledge base.

Furthermore, we find that the geography of knowledge sourcing differs considerably between knowledge channels. Monitoring is least bound to spatial proximity. Firms observe other organisations on the national and international level without engaging into direct interaction. They use internet platforms or specialised magazines to observe their competitors (Grabher and Ibert 2014) and attend international conferences and trade fairs, which has been stressed by the interview partners. By that means, they take advantage of temporary forms of proximity, which make physical co-location less vital (Bathelt and Gibson 2013). Collaboration takes place mostly locally, irrespective of the type of firms involved, which confirms the key role of proximity for interactive learning and the importance of local knowledge for symbolic 
innovation (Asheim, Boschma, and Cooke 2011). The third channel, labour mobility, appears to be even more localised. Among the interviewed firms, only one has hired internationally, while the majority recruits locally. Even in creative and cultural industries such as media, skilled workforce tends to stay in its home region and is reluctant to inter-regional job migration (Alfken et al., 2015). This shows that the local labour market is a key asset of the development of the cluster.

The paper calls for further research on the geography of innovation networks and combinatorial knowledge dynamics. The empirical analysis dealt with media firms located in a thick and diversified region, which raises the question to what extend the results can be generalized to other regional or industrial settings. It is reasonable to expect that firm of any industry located in peripheral regions have fewer knowledge sources available locally, and consequently a stronger need to reach out nationally and internationally. But then again, one can also expect that they have difficulties to collaborate externally and hire staff from outside the region, due to lower accessibility and a lack of urban amenities. Furthermore, the question raises whether the results are specific to the media industry, or whether firms in other industries have similar ways to acquire and combine knowledge. It is, for instance, reasonable to expect that firms in science-based industries have a strong tendency to source knowledge globally, due to the codifiability and universal applicability of analytical knowledge. Whether the results hold for other types of RIS and other types of industries are questions for future research. 


\section{References}

Alfken, Christoph. 2015. "Ich will nicht nach Berlin! - Life course analysis of inter-regional migration behaviour of people from the field of design and advertising." Environment and Planning A 47 (10):2187-2203. doi: 10.1177/0308518x15599287.

Alfken, Christoph, Tom Broekel, and Rolf Sternberg. 2015. "Factors Explaining the Spatial Agglomeration of the Creative Class: Empirical Evidence for German Artists." European Planning Studies 23 (12):2438-2463. doi: 10.1080/09654313.2014.979767.

Asheim, Bjørn. 2007. "Differentiated Knowledge Bases and Varieties of Regional Innovation Systems." Innovation: The European Journal of Social Science Research 20 (3):223241. doi: $10.1080 / 13511610701722846$.

Asheim, Bjørn, Lars Coenen, and Jerker Moodysson. 2015. "Methods and Applications of Regional Innovation Systems Analysis." In Handbook of Research Methods and Applications in Economic Geography, edited by Charlie Karlsson, Martin Andersson and Therese Norman, 272-291. Cheltenham: Edward Elgar.

Asheim, Bjørn T., Ron Boschma, and Philip Cooke. 2011. "Constructing regional advantage: platform policies based on related variety and differentiated knowledge bases." Regional Studies 45 (7):893-904. doi: 10.1080/00343404.2010.543126.

Asheim, Bjørn T., and Meric S. Gertler. 2005. "The Geography of Innovation: Regional Innovation Systems." In The Oxford Handbook of Innovation, edited by J. Fagerberg, D. C. Mowery and R. R. Nelson, 291-317. Oxford: Oxford University Press.

Asheim, Bjørn T., and Arne Isaksen. 2002. "Regional Innovation Systems: The Integration of Local 'Sticky' and Global 'Ubiquitous' Knowledge." The Journal of Technology Transfer 27 (1):77-86. doi: 10.1023/a:1013100704794.

Aslesen, Heidi Wiig, and Stefania Sardo. 2016. "Dynamic knowledge linkages and extended innovation." AAG Annual Meeting 2016, San Francisco

Audretsch, David B., and Maryann P. Feldman. 1996. "Innovative Clusters and the Industry Life Cycle." Review of Industrial Organization 11 (2):253-273. doi: 10.1007/bf00157670.

Balland, Pierre-Alexandre, Mathijs De Vaan, and Ron Boschma. 2013. "The dynamics of interfirm networks along the industry life cycle: The case of the global video game industry, 1987-2007." Journal of Economic Geography 13 (5):741-765. doi: $10.1093 / \mathrm{jeg} / \mathrm{lbs} 023$. 
Bathelt, Harald, and Rachael Gibson. 2013. "Learning in 'Organized Anarchies': The Nature of Technological Search Processes at Trade Fairs." Regional Studies 49 (6):985-1002. doi: 10.1080/00343404.2013.783691.

Belussi, F., and L. Pilotti. 2002. "Knowledge creation, learning and innovation in Italian Industrial districts." Geografiska Annaler: Series B, Human Geography 84 (2):125139. doi: 10.1111/j.0435-3684.2002.00118.x.

Belussi, Fiorenza. 2010. "In search of a useful theory of spatial clustering." In Clusters and Regional Development - Critical Reflections and Explorations, edited by Björn Asheim, Philip Cooke and Ron Martin, 69-97. New York: Routledge.

Belussi, Fiorenza, and Silvia R. Sedita. 2012. "Industrial Districts as Open Learning Systems: Combining Emergent and Deliberate Knowledge Structures." Regional Studies 46 (2):165-184. doi: 10.1080/00343404.2010.497133.

Boari, Cristina, Guido Fioretti, and Vincenza Odorici. 2008. "Rivalry and Learning among Clustered and Isolated Firms." Available at http://dx.doi.org/10.2139/ssrn.1145308.

Boschma, Ron. 2005. "Proximity and Innovation: A Critical Assessment." Regional Studies 39 (1):61-74. doi: 10.1080/0034340052000320887.

Boschma, Ron, Rikard Eriksson, and Urban Lindgren. 2009. "How does labour mobility affect the performance of plants? The importance of relatedness and geographical proximity." Journal of Economic Geography 9 (2):169-190. doi: 10.1093/jeg/lbn041.

Chaminade, Cristina, and Monica Plechero. 2015. "Do Regions Make a Difference? Regional Innovation Systems and Global Innovation Networks in the ICT Industry." European Planning Studies 23 (2):215-237. doi: 10.1080/09654313.2013.861806.

Cloke, Paul, and Ron. Johnston. 2005. Spaces of geographical thought: deconstructing human geography's binaries. London and Thousand Oaks: Sage.

Cohen, Wesley M., and Daniel A. Levinthal. 1990. "Absorptive Capacity: A New Perspective on Learning and Innovation." Administrative Science Quarterly 35 (1):128-152. doi: $10.2307 / 2393553$.

Cooke, Phil. 2010. "New media and new economy cluster dynamics." In Handbook of new media: Social shaping and social consequences of ICTs, Updated student edition, edited by Leah A Lievrouw and Paisley Livingston, 266-287. London: SAGE.

Cooke, Philip. 2002. "Regional Innovation Systems: General Findings and Some New Evidence from Biotechnology Clusters." The Journal of Technology Transfer 27 (1):133-145. doi: 10.1023/a:1013160923450. 
Cox, Kevin R. 2005. "Local: Global." In Spaces of geographical thought : deconstructing human geography's binaries, edited by Paul Cloke and Ron Johnston, 175-198. London and Thousand Oaks: Sage.

Currah, Andrew. 2009. What's Happening to Our News? An Investigation Into the Likely Impact of the Digital Revolution on the Economics of News Publishing in the UK. Oxford: Oxford University Press.

Fitjar, Rune Dahl, Franz Huber, and Andrés Rodríguez-Pose. 2016. "Not too close, not too far: testing the Goldilocks principle of 'optimal' distance in innovation networks." Industry and Innovation 23 (6):465-487. doi: 10.1080/13662716.2016.1184562.

Fitjar, Rune Dahl, and Andrés Rodríguez-Pose. 2011. "When Local Interaction Does Not Suffice: Sources of Firm Innovation in Urban Norway." Environment and Planning A 43 (6):1248-1267. doi: 10.1068/a43516.

Fitjar, Rune Dahl, and Andrés Rodríguez-Pose. 2013. "Firm collaboration and modes of innovation in Norway." Research Policy 42 (1):128-138. doi: 10.1016/j.respol.2012.05.009.

Frederiksen, Lars, and Silvia R Sedita. 2011. "Embodied Knowledge Transfer for Innovation: Comparing Interfirm Labor Mobility between Music and Manufacturing Industries." In Managing Networks of Creativity, edited by Fiorenza Belussi and Udo Hermann Staber, 103-125. Abingdon: Routledge.

Garmann Johnsen, Ingrid H. 2011. "Formal Project Organization and Informal Social Networks: Regional Advantages in the Emergent Animation Industry in Oslo, Norway." European Planning Studies 19 (7):1165-1181. doi: 10.1080/09654313.2011.573129.

Gertler, Meric S. 2003. "Tacit knowledge and the economic geography of context, or The undefinable tacitness of being (there)." Journal of Economic Geography 3 (1):75-99. doi: $10.1093 / \mathrm{jeg} / 3.1 .75$.

Gertler, Meric S. 2008. "Buzz without being there? Communities of practice in context." In Community, Economic Creativity, and Organization, edited by Ash Amin and Joanne Roberts, 203-226. Oxford: Oxford University Press.

Gioia, Dennis A., and Charles C. Manz. 1985. "Linking Cognition and Behavior: A Script Processing Interpretation of Vicarious Learning." Academy of Management Review 10 (3):527-539. doi: 10.5465/amr.1985.4278987.

Giuliani, Elisa, and Carlo Pietrobelli. 2014. "Social network analysis methodologies for the evaluation of cluster development programs." Papers in Innovation Studies 2014/11. 
Grabher, Gernot. 2002. "Fragile sector, robust practice: project ecologies in new media." Environment and Planning A 34 (11):1911-1926. doi: 10.1068/a35256.

Grabher, Gernot, and Oliver Ibert. 2006. "Bad company? The ambiguity of personal knowledge networks." Journal of Economic Geography 6 (3):251-271. doi: 10.1093/jeg/lbi014.

Grabher, Gernot, and Oliver Ibert. 2014. "Distance as asset? Knowledge collaboration in hybrid virtual communities." Journal of Economic Geography 14 (1):97-123. doi: $10.1093 / \mathrm{jeg} / \mathrm{lbt} 014$.

Grillitsch, Markus, Roman Martin, and Martin Srholec. 2016. "Knowledge Base Combinations and Innovation Performance in Swedish Regions." Economic Geography forthcoming. doi: 10.1080/00130095.2016.1154442.

Groot Kormelink, Tim, and Irene Costera Meijer. 2014. "Tailor-Made News." Journalism Studies 15 (5):632-641. doi: 10.1080/1461670X.2014.894367.

Hansen, Høgni Kalsø, and Thomas Niedomysl. 2009. "Migration of the creative class: evidence from Sweden." Journal of Economic Geography 9 (2):191-206. doi: 10.1093/jeg/lbn046.

Hansen, Teis. 2015. "Substitution or Overlap? The Relations between Geographical and Nonspatial Proximity Dimensions in Collaborative Innovation Projects." Regional Studies 49 (10):1672-1684. doi: 10.1080/00343404.2013.873120.

Hassink, Robert. 2010. "Locked in Decline? On the Role of Regional Lock-ins in Old Industrial Areas." In The Handbook of Evolutionary Economic Geography, edited by Ron Boschma and Ron Martin, 450-468. Cheltenham: Edward Elgar.

Herstad, Sverre J., Heidi Wiig Aslesen, and Bernd Ebersberger. 2014. "On industrial knowledge bases, commercial opportunities and global innovation network linkages." Research Policy 43 (3):495-504. doi: 10.1016/j.respol.2013.08.003.

Herstad, Sverre J., Tore Sandven, and Bernd Ebersberger. 2015. "Recruitment, knowledge integration and modes of innovation." Research Policy 44 (1):138-153. doi: 10.1016/j.respol.2014.06.007.

Huber, Franz. 2012. "On the Sociospatial Dynamics of Personal Knowledge Networks: Formation, Maintenance, and Knowledge Interactions." Environment and Planning A 44 (2):356-376. doi: 10.1068/a44239.

Huber, George P. 1991. "Organizational Learning: The Contributing Processes and the Literatures." Organization Science 2 (1):88-115. doi: 10.1287/orsc.2.1.88. 
Ingstrup, Mads Bruun, Susanne Jensen, and Poul Rind Christensen. 2017. "Cluster evolution and the change of knowledge bases: the development of a design cluster." European Planning Studies 25 (2):202-220. doi: 10.1080/09654313.2016.1276885.

Isaksen, Arne, and Michaela Trippl. 2016. "Path Development in Different Regional Innovation Systems: A Conceptual Analysis." In Innovation Drivers and Regional Innovation Strategies, edited by Mario Davide Parrilli, Rune Dahl Fitjar and Andrés Rodriguez-Pose, 66-84. New York: Routledge.

Jakobsen, Stig-Erik, and Torbjørn Lorentzen. 2015. "Between bonding and bridging: Regional differences in innovative collaboration in Norway." Norsk Geografisk Tidsskrift Norwegian Journal of Geography 69 (2):80-89. doi:

10.1080/00291951.2015.1016550.

Jenkins, Henry. 2006. Convergence Culture: When Old and New Media Collide. New York: New York University Press.

Johnson, Björn, Edward Lorenz, and Bengt-Åke Lundvall. 2002. "Why all this fuss about codified and tacit knowledge?" Industrial and Corporate Change 11 (2):245-262. doi: 10.1093/icc/11.2.245.

Knoben, J., and L. A. G. Oerlemans. 2006. "Proximity and inter-organizational collaboration: A literature review." International Journal of Management Reviews 8 (2):71-89. doi: 10.1111/j.1468-2370.2006.00121.x.

Laestadius, Staffan. 1998. "Technology Level, Knowledge Formation and Industrial Competence in Paper Manufacturing." In The Micro Foundations of Economic Growth, edited by G. Eliasson and C. Green, 212-226. Ann Arbour: University of Michigan Press.

Lazzeretti, Luciana, Rafael Boix, and Francesco Capone. 2008. "Do Creative Industries Cluster? Mapping Creative Local Production Systems in Italy and Spain." Industry and Innovation 15 (5):549-567. doi: 10.1080/13662710802374161.

Lorenzen, Mark, and Ram Mudambi. 2013. "Clusters, Connectivity and Catch-up: Bollywood and Bangalore in the Global Economy." Journal of Economic Geography 13 (3):501534. doi: $10.1093 / \mathrm{jeg} / \mathrm{lbs} 017$.

Malmberg, Anders, and Peter Maskell. 2002. "The elusive concept of localization economies: towards a knowledge-based theory of spatial clustering." Environment and Planning A 34 (3):429-449. doi: 10.1068/a3457. 
Manniche, Jesper, and Karin T Larsen. 2013. "Experience staging and symbolic knowledge: The case of Bornholm culinary products." European Urban and Regional Studies 20 (4):401-416. doi: 10.1177/0969776412453146.

Manniche, Jesper, Jerker Moodysson, and Stefania Testa. 2016. "Combinatorial Knowledge Bases: An Integrative and Dynamic Approach to Innovation Studies." Economic Geography:1-20. doi: 10.1080/00130095.2016.1205948.

Martin, Roman. 2013. "Differentiated Knowledge Bases and the Nature of Innovation Networks." European Planning Studies 21 (9):1418-1436. doi: 10.1080/09654313.2012.755836.

Martin, Roman, and Jerker Moodysson. 2011. "Innovation in Symbolic Industries: The Geography and Organization of Knowledge Sourcing." European Planning Studies 19 (7):1183-1203. doi: 10.1080/09654313.2011.573131.

Martin, Roman, and Jerker Moodysson. 2013. "Comparing Knowledge Bases: On the Geography and Organization of Knowledge Sourcing in the Regional Innovation System of Scania, Sweden." European Urban and Regional Studies 20 (2):170-187. doi: $10.1177 / 0969776411427326$.

Martin, Roman, and Michaela Trippl. 2015. "Cluster Evolution, Regional Innovation Systems and Knowledge Bases: The Development and Transformation of the ICT Cluster in Southern Sweden." Papers in Innovation Studies No. 2015/24.

Mattes, Jannika. 2012. "Dimensions of Proximity and Knowledge Bases: Innovation between Spatial and Non-spatial Factors." Regional Studies 46 (8):1085-1099. doi: 10.1080/00343404.2011.552493.

McKelvey, Maureen, and Bastian Rake. 2016. "Product innovation success based on cancer research in the pharmaceutical industry: co-publication networks and the effects of partners." Industry and Innovation 23 (5):383-406. doi: 10.1080/13662716.2016.1150157.

Menzel, Max-Peter. 2015. "Interrelating Dynamic Proximities by Bridging, Reducing and Producing Distances." Regional Studies 49 (11):1892-1907. doi: 10.1080/00343404.2013.848978.

Moodysson, Jerker. 2007. Sites and modes of knowledge creation: on the spatial organization of biotechnology innovation. Lund: Lund University Press.

Moodysson, Jerker. 2008. "Principles and Practices of Knowledge Creation: On the Organization of "Buzz" and "Pipelines" in Life Science Communities." Economic Geography 84 (4):449-469. doi: 10.1111/j.1944-8287.2008.00004.x. 
Morgan, Kevin. 2004. "The exaggerated death of geography: learning, proximity and territorial innovation systems." Journal of Economic Geography 4 (1):3-21. doi: 10.1093/jeg/4.1.3.

Mossig, Ivo. 2004. "The networks producing television programmes in the Cologne media cluster: new firm foundation, flexible specialization and efficient decision making structures." European Planning Studies 12 (2):155-171. doi: $10.1080 / 0965431042000183914$.

Moulaert, Frank, and Farid Sekia. 2003. "Territorial innovation models: A critical survey." Regional Studies 37 (3):289-302. doi: 10.1080/0034340032000065442.

Neffke, Frank, and Martin Henning. 2013. "Skill relatedness and firm diversification." Strategic Management Journal 34 (3):297-316.

Niedomysl, Thomas, and Høgni Kalsø Hansen. 2010. "What Matters more for the Decision to Move: Jobs versus Amenities." Environment and Planning A 42 (7):1636-1649. doi: $10.1068 / \mathrm{a} 42432$.

Nonaka, Ikujiro, Ryoko Toyama, and Noboru Konno. 2000. "SECI, Ba and Leadership: a Unified Model of Dynamic Knowledge Creation." Long Range Planning 33 (1):5-34. doi: 10.1016/S0024-6301(99)00115-6.

Nooteboom, Bart, Wim Van Haverbeke, Geert Duysters, Victor Gilsing, and Ad van den Oord. 2007. "Optimal cognitive distance and absorptive capacity." Research Policy 36 (7):1016-1034. doi: 10.1016/j.respol.2007.04.003.

North, Douglass C. 1990. Institutions, institutional change and economic performance, Political economy of institutions and decisions. Cambridge: Cambridge University Press.

Norway, Innovation. 2015. NORWEGIAN CLUSTERS 2015 for the future's innovative industries. edited by Innovation Norway. Oslo.

Pina, Katia, and Bruce S. Tether. 2016. "Towards understanding variety in knowledge intensive business services by distinguishing their knowledge bases." Research Policy 45 (2):401-413. doi: 10.1016/j.respol.2015.10.005.

Plum, Oliver, and Robert Hassink. 2011. "Comparing knowledge networking in different knowledge bases in Germany." Papers in Regional Science 90 (2):355-371. doi: 10.1111/j.1435-5957.2011.00362.x.

Plum, Oliver, and Robert Hassink. 2014. "Knowledge bases, innovativeness and competitiveness in creative industries: the case of Hamburg's video game developers." 
Regional Studies, Regional Science 1 (1):248-268. doi:

10.1080/21681376.2014.967803.

Polanyi, Michael. 1967. The Tacit Dimension. New York: Doubleday.

RCN. 2013. Virkemidler for regional FoU og innovasjon (VRI) - Programplan 2014-2017. edited by The Research Council of Norway (RCN). Oslo: The Research Council of Norway (RCN).

Robertson, Paul L, and Keith Smith. 2008. "Distributed knowledge bases in low- and medium-technology industries." In Innovation in Low-Tech Firms and Industries, edited by Hartmut Hirsch-Kreinsen and David Jacobson, 93-117. Cheltenham: Edward Elgar.

Sayer, Andrew. 1992. Method in Social Science: A Realist Approach (Revised 2nd Edition). London: Routledge.

Srholec, Martin, and Bart Verspagen. 2012. "The Voyage of the Beagle into innovation: explorations on heterogeneity, selection, and sectors." Industrial and Corporate Change 21 (5):1221-1253. doi: 10.1093/icc/dts026.

Timmermans, Bram, and Ron Boschma. 2014. "The effect of intra- and inter-regional labour mobility on plant performance in Denmark: the significance of related labour inflows." Journal of Economic Geography 14 (2):289-311. doi: 10.1093/jeg/lbs059.

Torre, André. 2008. "On the Role Played by Temporary Geographical Proximity in Knowledge Transmission." Regional Studies 42 (6):869-889. doi: $10.1080 / 00343400801922814$.

Torre, André, and Jean-Pierre Gilly. 2000. "On the Analytical Dimension of Proximity Dynamics." Regional Studies 34 (2):169-180. doi: 10.1080/00343400050006087.

Trippl, Michaela. 2013. "Scientific Mobility and Knowledge Transfer at the Interregional and Intraregional Level." Regional Studies 47 (10):1653-1667. doi: 10.1080/00343404.2010.549119.

Turow, Joseph. 2005. "Audience Construction and Culture Production: Marketing Surveillance in the Digital Age." The ANNALS of the American Academy of Political and Social Science 597 (1):103-121. doi: 10.1177/0002716204270469.

Tödtling, Franz, Bjørn Asheim, and Ron Boschma. 2013. "Knowledge sourcing, innovation and constructing advantage in regions of Europe." European Urban and Regional Studies 20 (2):161-169. doi: 10.1177/0969776412457173. 
Tödtling, Franz, and Markus Grillitsch. 2015. "Does Combinatorial Knowledge Lead to a Better Innovation Performance of Firms?" European Planning Studies 23 (9):17411758. doi: 10.1080/09654313.2015.1056773.

van Egeraat, Chris, Sean O'Riain, and Aphra Kerr. 2013. "Social and Spatial Structures of Innovation in the Irish Animation Industry." European Planning Studies 21 (9):14371455. doi: 10.1080/09654313.2012.755838.

Vang, Jan, and Cristina Chaminade. 2007. "Cultural Clusters, Global-Local Linkages and Spillovers: Theoretical and Empirical Insights from an Exploratory Study of Toronto's Film Cluster." Industry and Innovation 14 (4):401-420. doi: $10.1080 / 13662710701523942$. 